year to the parish officers; in many cases the parish practice was the best and most profitable part of a country surgeon's practice. I admit it would be much more honourable and respectable on the part of the guardians, were they to fix a fair remunerating sum, according to the number of paupers and the size of the district; and I think such a plan is practicable. The competitors for the situation would then be on an equal footing, as to the emolument to be derived from the office. Should you consider these observations suitable for the Provincial Medical and Surgical Journal, your inserting them in an early number will oblige your obedient servant,

Bath, Dec. 8th, 1841.

George King.

$*_{*}^{*}$ We give insertion to the letter of Mr. King, as a matter of curiosity. A defence of the poor-law commissioners, and of the tender system, from the pen of a medical man, is really a phenomenon. For a refutation of Mr. King's arguments, we have only to refer to the poor-law report of the provincial association, the concluding portion of which is contained in our present number,-EDS,

\section{THE TENDER SYSTEM.}

TO THE EDITORS OF THE PROVINCIAL MEDICAL AND SURGICAL JOURNAL.

Gentreman,-I greatly regret that I am compelled to occupy the pages of your valuable Journal, with matter of so little worth to the profession at large, but I cannot allow Mr. Chalk's explanatory letter to pass over, without explaining away the errors it contains. I think, gentlemen, the simple fact of my not replying to Mr. Vale's inquiry, is a sufficient proof that it was not the person, but the system, which I attacked; and as I have always lived on terms of friendliness with my medical brethren, regret that any thing should occur to break that bond of union which has subsisted amongst us. Mr. Chalk observes, that upon the resignation of the late medical officer, "an advertisement was subsequently put forth, and an active canvass took place by four candidates," including myself in the number. I beg distinctly to state, that the steps which I took towards obtaining the appointment.were effected long before the appearance of that advertisement, which announced that the election should take place by tender. $\mathrm{Mr}$. C__ goes on to observe, "so strenuous was he in the cause, that he not only canvassed, but sent to all the guardians and directors a note," \&c.; and that "after all this extraordinary exertion, he withdrew himself from the contest. Whether he was suddenly disgusted with the tender system, or found that he had not sufficient strength, I cannot say." To be as concise as possible, I would remark that, owing to the solicitations of my friends, some of whom possess considerable influence at the "quarterly board," I did send a circular, \&c., to some of the directors and guardians ; but "so strenuous was I in the cause," and so "extraordinary" were my "exertions," that I personally "canvassed"-not all, but, to the best of my recollection, only one of the directors or guardians. You must bear in mind, gentlemen, that up to this period I was unaware that the election would take place by tender; and as soon as I ascertained this circumstance, I went so far as to inform one of the candidates that I had declined the contest. My disgust towards the tender system arose from no sudden impression, for at a similar election, some few years ago, I then refused to "seek office," on account of the method employed. As to my not having "sufficient strength," I must take leave to say that I have been longer established in this, my native parish, than the gentleman who has undertaken the respon- sible office of a medical attendant upon the poor, resident in eight parishes, at the salary of $£ 16$ per annum. Having handled the subject as tenderly as circumstances would admit, believe me to remain, Gentlemen, Your obedient servant,

Lowestoft, Dec. 14, 1841. Saluel S. Brame.

\section{REMUNERATION OF GENERAL PRACTI- TIONERS.}

TO THE EDITORS OF THE PROVINCIAL SURGICAL AND MEDICAL JOURNAL.

Gentlemen,-In your periodical for the 4 th of December, I observed a letter from Dr. Tunstall, on the propriety of medical practitioners taking certain fees in lieu of charging for their medicine. I perfectly agree with Dr. Tunstall in all he says so far, but differ with him in his suggestion for turning the whole of the dispensing over to the druggists. For, in the first place, it would be attended with great inconvenience, and send every patient in the country to a druggist's shop, often many miles distant; and, secondly, we could not always depend upon the accuracy of their dispensing and the quality of the drugs. The best and most honourable way would be to charge fees and supply the medicine gratis. And, in order that all parties might have medical aid, the fee should range from half-a-crown to two guineas for each attendance, surgical operations excepted. Such fees to be made legal, and recoverable by Act of Parliament. This plan would meet the circumstances of all grades of society; nor need any body complain of the charge, for it would be easy for the patient to ask "What is your fee?" or for the surgeon to say my fee is so and so, thereby giving the patient the option of going to one whose fee was less.

\section{Your obedient servant,} W. Johnsos,

Watlington Cottage, Dec. 14, 1841.

\section{NEW EDITION OF MÜLLER'S PHYSIOLOGY.}

TO TIIE EDITORS OF THE PROVINCIAL MEDICAL AND SURGICAL, JOURNAL.

Gentlemen,-May I beg the favour of the insertion of a few iines, in your widely-circulated Journal, in the hope that they may reach the glance of the able translator, or publisher of Müller's Physiology? In common with many others, I subscribed for that work, when the first part appeared; since then, and previous to the publication of the last part, a second edition of the first vol. has been issued, with, I observe (from the references and errata in last part), considerable additions, and of course, improvements. Whilst gladly congratulating those gentlemen on its extended sale, I would appeal to their justice and liberality, whether those who subscribed at the beginning should, in consequence, possess a less valuable copy, and whether the improvements in question might not be furmished separately, or the spirit of them, in an appendix, with the last part, to the early subscribers; as one I should cheerfully be at additional expense, to possess the best edition of so valuable a work, and should not now complain, had the work been completely published, however soon a new edition might appear; but in the present instance, should the above suggestion not be complied with, in the absence of any fault on our part, we shall each possess an inferior edition. I am, Gentlemen, yours faithfully,

Newcastle-on-Tyne, Dec. 11, 1841.
S. Knotr. 